\title{
Cerberus Fossae, Mars: The case for dike intrusion-related formation and modification
}

\author{
Amanda L. NAHM $^{1,2}$, Matthew W. PENDLETON ${ }^{2,3}$, and Simon A. KATTENHORN ${ }^{2,4}$ \\ ${ }^{1}$ German Aerospace Center (DLR), Rutherfordst. 2, 12489 Berlin, Germany; ${ }^{2}$ University of \\ Idaho, 875 Perimeter Dr. Moscow, Idaho 83844 USA; ${ }^{3}$ Earth Consultants International, 1642 \\ E. 4th St., Santa Ana, California 92701 USA; ${ }^{4}$ University of Alaska Anchorage, 3211 \\ Providence Dr., CPISB 101, Anchorage, Alaska 99508 USA \\ E-mail: amanda.nahm@dlr.de
}

Cerberus Fossae (CF) is a large fracture system on Mars that extends for more than $1200 \mathrm{~km}$. The structures, or fossae, are southeast of, and oriented approximately radially to, the large shield volcano Elysium Mons. An individual fossa, or long narrow depression, can be up to 2 $\mathrm{km}$ wide and $1 \mathrm{~km}$ deep. This radial orientation of $\mathrm{CF}$ may reflect dike intrusions related to Elysium Mons (e.g., Berman and Hartmann, 2002; Burr et al., 2002a; Head et al., 2003; Plescia, 2003; Vetterlein and Roberts, 2010), a pattern typical of large intrusions on terrestrial bodies (e.g., Ernst et al., 2001).

Cerberus Fossae has long been recognized as a source of both lava and water (e.g., Plescia, 1990, 2003; Burr et al., 2002a,b). Volcanic and fluvial activity appear to have been contemporaneous, based on observations of fluvial outflow channels that both cut and are filled by lava flows (Berman and Hartmann, 2002). Formation of the fossae within CF is likely very young, based on crater counting of volcanic units cut by CF [ 200 Ma or younger (Berman and Hartmann, 2002; Vaucher et al., 2009)].

Several hypotheses for the formation and modification of the fossae that have been proposed include purely tectonic (e.g., Berman and Hartmann, 2002; Vetterlein and Roberts, 2009, 2010) and volcanic/magmatic (e.g., Head et al., 2003; Mège and Masson, 1996; Burr et al., 2002a; Hanna and Phillips, 2006; Taylor et al., 2013; Pendleton, 2015) processes. At present, the primary or dominant formation mechanism remains under debate. Here, we present evidence in support of a dike-dominated mechanism for the formation and/or modification of Cerberus Fossae.

Diagnostic landforms indicative of volcanic or dike activity may have been destroyed by the complicated history of the CF region. For example, constructional landforms along CF may have been destroyed by normal faulting (Keszthelyi et al., 2008), likely the most recent geologic event at Cerberus (e.g., Berman and Hartmann, 2002; Burr et al., 2002a,b; Taylor et al., 2013), or melting of abundant ground ice (e.g., Balme and Gallagher, 2009) from dike intrusion. In addition, the typical topographic signatures resulting from dike intrusion at depth (e.g., Rubin and Pollard, 1988) may have been obscured or destroyed by lava flows and/or hydrothermal alteration of the fossae marginal zones (e.g., Pendleton, 2015).

Multiple lines of evidence for volcanic activity associated with the CF exist. For example, linear fissure vents and low shields have been identified (e.g., Plescia, 2003; Vaucher et al., 2009), as well as multiple lava flows sourced by the CF (e.g., Jaeger et al., 2010; Keszthelyi et al., 2004; Vaucher et al., 2009). Keszthelyi et al. (2008) provide details of near-vent deposits at CF.

Recent analysis of the CF geomorphology (Pendleton, 2015) reveals evidence for local hydrothermal modification of surfaces near the fossae margins, which is indicative of longlived interactions of dikes and ground ice. Adjacent to fossae, depressions with multiple 
morphologies have been observed, including those with multiple nested terraces, and evidence of flow away from the fossae margins (Pendleton, 2015). These strongly imply interaction between an ice-rich subsurface and an underlying heat source (i.e., a dike) (Pendleton, 2015).

These observations, together with previous work, combine to form a coherent picture of the formation and modification of the structures at Cerberus Fossae that requires underlying dikes (Figure 1) (Pendleton, 2015): 1) Heat from dike intrusion resulted in elongate depressions above the dikes from melting of subsurface ice and a subsurface hydrothermal system. 2) Water release formed outflow channels (i.e., Athabasca Valles and others) in some locations. 3) Volcanic eruptions filled the depressions formed in the first stage, resulting in lava ponds that emptied during subsequent breakouts, creating lobate flows away from the fossae. 4) Hydrothermal systems modified the fossae margins after volcanism ceased, resulting in fossae widening from groundwater seepage and deepening from vertical faults or dike evacuation. Fossa walls crosscut depressions and channels around the margins of the fossae and in some cases, these depressions may crosscut fossae, indicating that dike-induced hydrothermal systems at Cerberus Fossae were long-lived.

Acknowledgement: ALN is supported by the Alexander von Humboldt Stiftung/Foundation.
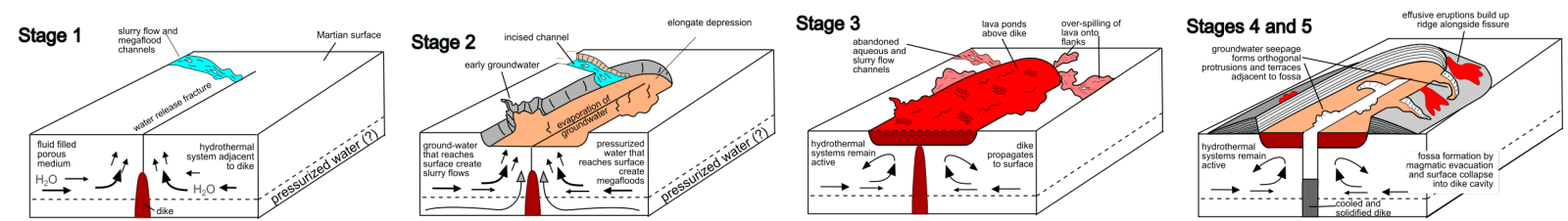

Figure 1. Proposed formation mechanism for Cerberus Fossae. All processes shown require the presence of a subsurface dike and an ice-rich cryosphere that provided fluids mobilized in a hydrothermal system. Modified from Pendleton (2015).

\section{References}

Balme, MR, Gallagher, CJ, 2009. An equatorial periglacial landscape on Mars, EPSL, 285, 115.

Berman, DC, Hartmann, WK, 2002. Recent fluvial, volcanic, and tectonic activity on the Cerberus plains of Mars. Icarus, 159, 1-17.

Burr, DM, et al., 2002a. Repeated aqueous flooding from the Cerberus Fossae: Evidence for very recently extant, deep groundwater on Mars, Icarus, 159, 53-73.

Burr, DM, McEwen, AS, Sakimoto, SEH, 2002b. Recent aqueous floods from the Cerberus Fossae, Mars, Geophys. Res. Lett., 29.

Ernst, RE, Grofils, EB, Mège, D, 2001, Giant dike swarms: Earth, Venus, and Mars, Ann. Rev. Earth Planet. Sci., 29, 489-534.

Hanna, JC, Phillips, RJ, 2006, Tectonic pressurization of aquifers in the formation of Mangala Valles, Mars, JGR, 111, E03003.

Head, JW, Wilson, L, Mitchell, KL, 2003, Generation of recent massive water floods at Cerberus Fossae, Mars by dike emplacement, cryospheric cracking, and confined aquifer groundwater release. GRL, 30, 1577.

Jaeger, WL, et al. 2010, Emplacement of the youngest flood lava on Mars: A short, turbulent story, Icarus, 205, 230-243.

Keszthelyi, L, et al., 2004. Icelandic analogs to Martian flood lavas. Geochem. Geophys. Geosyst. 5, Q11014. 
Keszthelyi, L, et al., 2008, High Resolution Imaging Science Experiment (HiRISE) Images of Volcanic Terrains from the First 6 Months of the Mars Reconnaissance Orbiter Primary Science Phase. JGR, 113, E04005.

Mège, D, Masson, P, 1996, A plume tectonics model for the Tharsis province, Mars, Planet. Space Sci., 44, 1499-1546.

Pendleton, MW, 2015, Geomorphic evidence for geologically recent groundwater flow associated with the Cerberus Fossae magmatic and volcanic system, Mars, MSc. thesis, University of Idaho, $157 \mathrm{pp}$.

Plescia, JB, 1990, Recent Flood Lavas in the Elysium Region of Mars. Icarus 88, 465-490.

Plescia, JB, 2003, Cerberus Fossae, Elysium, Mars: a source for lava and water. Icarus 164, 7995.

Rubin, AM, Pollard, DD, 1988, Dike-induced faulting in rift zones of Iceland and Afar. Geology, 16, 413-417.

Taylor, J, Teanby, NA, Wookey, J, 2013, Estimates of seismic activity in the Cerberus Fossae region of Mars, JGR Planets, 118, 2570-2581.

Vaucher, J, et al., 2009, The volcanic history of central Elysium Planitia: Implications for martian magmatism, Icarus, 204, 418-442.

Vetterlein, J, Roberts, GP, 2009, Postdating of flow in Athabasca Valles by faulting of the Cerberus Fossae, Elysium Planitia, Mars, JGR, 114, E07003.

Vetterlein, J, Roberts, GP, 2010, Structural evolution of the Northern Cerberus Fossae graben system, Elysium Planitia, Mars. J. Struct. Geol., 32, 394-406. 